\title{
Investigation of the Relationship Between the Leisure and Stepping Frequencies of the Students Receiving Recreation Education
}

\author{
Aytekin Alpullu ${ }^{1}$, Gökalp Demir ${ }^{1}$ \\ ${ }^{1}$ Marmara University, Faculty of Sports Sciences, Istanbul, Turkey \\ Correspondence: Aytekin Alpullu, Marmara University, Faculty of Sports Sciences, Istanbul, Turkey.
}

Received: November 14, 2018

Accepted: December 12, 2018

Online Published: January 3, 2019

doi:10.11114/jets.v7i2.3767

URL: https://doi.org/10.11114/jets.v7i2.3767

\begin{abstract}
The simplest and easiest type of physical activity for a healthy individual is walking. Development of technology day by day brought along inactivity and related diseases. The purpose of exercise is to prevent and slow down diseases caused by a sedentary lifestyle. The aim of the study is to reveal the effect of walking on body composition of the individual and to investigate the relationship between the stepping frequency before and after taking a recreation course of the students studying at the faculty of sports sciences.

A total of 150 volunteers consisting of 97 males and 53 females aged between 18-26 and older participated in the study. The study lasted 12 weeks. The daily stepping frequencies of all participants were recorded with the pedometer program on their mobile phones. The recreation course was given as two hours of lectures per week to the students studying in three departments (teaching, coaching, management).

As a result of the correlation test used in this study, the stepping frequency was found to be increased after the recreation course was explained. Awareness was created after the lecturing. No significant relationship was found between this awareness and the age of males and females, and between this awareness and the number of distance and daily steps taken.
\end{abstract}

Keywords: daily stepping, college student, recreation, leisure

\section{Introduction}

With the developing technology, industrialization and the different lifestyles of urbanization, increased economic efficiency, decreasing work hours, conscious valuing of leisure arising from vacations with pay have resulted in positive manners. The negative aspect is that the work and living conditions alienate the person to society in industrialized societies (Önsoy,1984:236). The way to overcome this negativity is to create a leisure time opportunity to socialize people and renew themselves with physical activities. In the studies, it is stated that increasing the positive use of leisure time contributes to growing of healthy young people (Balc1 and Demirtaş,2002:123). In a written master's thesis supporting this idea, it is stated that cultural, social and skill infrastructures are effective in order to be successful in scientific and social life (Yağmur, 2006).

Especially the importance of the consciously value the leisure time of young people living in big cities in terms of the future of the country was emphasized. The reason for this is the fact that university students will be the ones who determine the future of a country in terms of their future position and therefore not only occupational aspect, but also the importance of the social, physical and spiritual education of young people through multi-faceted education programs were underlined in terms of the country's future (Mansuroğlu, 2002). Emphasized that each age period shows distinct characteristics in the evaluation of leisure time, there are biological, psychological intense changes during the youth period and he emphasizes the importance for society (Süzer,1997). In another study, it was concluded that most of the youth of the university do not know how to value their leisure time, spend their time with passive activities and are willing to participate in active events (Demir,2003). Stated that participation in sporting activities in the open field had positive effects on people. He found that these activities had positive effects on physical, mental and social health (Mc Avoy,2001:24). He also stated that these activities increase one's self-confidence, personal skill and social behavior and contribute to personality development. Increasing the number of daily steps of students is important both for their health and for creating an awareness of individuals for learning and exploring outdoor spaces. It has been determined that having an inactive life causes some functional abilities to decrease and invites many diseases (Özer,2006:21). Diseases occurring in an inactive body are defined as hypokinetic diseases. Inactive life causes 
vascular occlusion and increases the risk of heart attack, high blood pressure and cholesterol, obesity, and most importantly, the risk of defects and disorders in the musculoskeletal system. Zorba (1999) says that 30 minutes of walking or $150 \mathrm{kcal}$ of energy consumption per day, or a moderate exercise reduces coronary heart disease by $50 \%$ and high blood pressure, diabetes and colon cancer by $30 \%$, as well. It is recommended to perform a moderate activity on average for 30 minutes daily by ACSM The American College of Sports Medicine (ACSM,1995) and Centers for Disease Control and Prevention (CDC:1196) (Pate,Blair and Haskel,1995), U.S. Department (1996). The aim of this study is to give the students of the 3rd and 4th grades of the Faculty of Sport Sciences a recreation training and to explain the importance of taking step in their leisure time. The awareness that physical activity is not limited to sports activities and planned entertainment was aroused and the fact that physical activity opportunities exist everywhere was emphasized.

In this context, informative information was presented in the evaluation of leisure time and awareness of physical activity was given. This study covers the examination of the importance of the number of steps taken with the help of variables such as age, gender and distance between the place of residence and school.

\section{Methodology}

The aim of this study was to determine the difference between the steps taken by the students in the Faculty of Sport Sciences in Istanbul before and after the recreation course and thus to investigate the relationship in terms of demographic.

\subsection{Sample Goup}

This study aims to ensure that students studying at the faculty of sports sciences will become aware of the number of daily steps taken from the point that they will be an important element of the society in the future. The study was carried out on 150 students studying in three faculties.

The personal information form was prepared by the researcher and the data were collected to provide data on the socio-demographic characteristics of the participants. The necessary permissions for the research were taken by the students themselves.

Table 1. Demographic characteristics of the students in the sample group

\begin{tabular}{|c|c|c|c|c|}
\hline & Independent Variable & $\begin{array}{l}\text { Frequency } \\
\mathbf{N}=\mathbf{1 5 0}\end{array}$ & Percent & Cumulative Percent \\
\hline \multirow[t]{2}{*}{ GENDER } & Woman & 53 & 35,3 & 35,3 \\
\hline & Man & 97 & 64,7 & 100,0 \\
\hline \multirow[t]{3}{*}{ FACULTY DEPARTMENT } & Sport management & 23 & 15,3 & 15,3 \\
\hline & Physical education & 42 & 28 & 43,3 \\
\hline & Sport coaching & 85 & 56,7 & 100,0 \\
\hline \multirow[t]{5}{*}{ AGE } & $18-19$ & 13 & 8,7 & 8,7 \\
\hline & $20-21$ & 42 & 28,0 & 59,3 \\
\hline & $22-23$ & 61 & 40,7 & 100,0 \\
\hline & $24-25$ & 20 & 13,3 & 31,3 \\
\hline & 26 - over & 14 & 9,3 & 18,0 \\
\hline DİSTANCE FROM & $0-6 \mathrm{~km}$ & 35 & 23,3 & 31,3 \\
\hline \multirow[t]{2}{*}{ HOME OF FACULTY } & $7-40 \mathrm{~km}$ & 103 & 68,7 & 100,0 \\
\hline & $40 \mathrm{~km}$-over & 12 & 8,0 & 8,0 \\
\hline
\end{tabular}

The number of male students participating in our study was 97 (64.7\%) and the number of female students was 53 (35.3\%). Among the students studying in the Faculty of Sport Sciences and taking courses in three departments, 23 students $(15.3 \%)$ from the sports management department, 42 from the teaching department (28\%) and 85 from the coaching department (56.7\%) participated in the study. When the ages were examined, the study group included at least 22-23 (40.7\%) age group and at least 18-19 age group (13\%). In order to determine the distance between the student's place of residence and the school in terms of the importance of the average number of stepping frequencies, 103 (68.7\%) students stated that they resided within 7-40 km. 35 students (23.3\%) were identified living in a distance between 0-6 $\mathrm{km}$ and 12 of them (8\%) in $40 \mathrm{~km}$ and over.

Not to create a conscious perception on students before the recreation course is given, data was collected from the students having pedometer application on their mobile phones. However, this data was included in the study as it was recorded as the data of the person on average monthly. This study is advantageous in that it can be done without cost and without any need for laboratory environment and any additional material, and data can be received and applied from more than one person at the same time.

The questionnaire form was also prepared in the form of demographic information questions. Statistical data were evaluated in SPSS 17.0 program and frequency percentages were shown as tables with simple correlation test with Paired Samples T-Test. 


\section{Findings}

Table 2. K-S test results

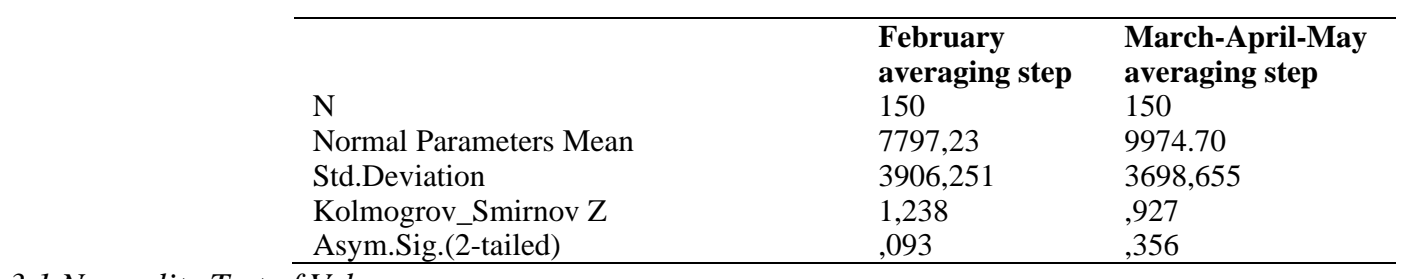

\subsection{Normality Test of Values}

Findings obtained, according to the observed stepping frequencies, before the lecture, in February, the KS values of the stepping frequency was , $10 \mathrm{p}=, 093$; after the lecture, in March-April-May stepping frequency $(\mathrm{KS}=, 07, \mathrm{p}=, 356)$ comes from a normal distributed mass.

$\mathrm{H}_{1}$ :There is a significant relationship between the stepping frequencies before and after the lecture.

Table 3. Related samples t test results

\begin{tabular}{lcccccc}
\hline Assumptions & $\mathbf{N}$ & Average & $\begin{array}{c}\text { Standard } \\
\text { Deviation }\end{array}$ & $\begin{array}{c}\text { Free } \\
\text { value }\end{array}$ & $\mathbf{t}$ & $\mathbf{P}$ \\
first test step & 150 & 7797 & 3906,251 & 149 & $-4,921$ &, 000 \\
final test step & 150 & 8974 & 4249,224 & & & \\
\hline
\end{tabular}

Whether the students showed a significant difference between the assumptions of stepping after taking a recreation lesson and taking the course was investigated on the data obtained from 150 students.

According to the findings, a significant difference was found between the average of the steps taken before taking the course and the average of the next step after taking the course $(t=-4,921$ and $p=0.05)$. The stepping average of students after the lecture (8974 steps) was higher than the average (7797 steps) before the lecture. According to these results, $\mathrm{H}_{1}$ hypothesis was accepted. In other words, there is a significant difference between the assumptions of the Recreation course after the students take the course and before they take the course.

Table 4. Simple correlation results

\begin{tabular}{|c|c|c|}
\hline & $\begin{array}{l}\text { February } \\
\text { averaging } \\
\text { step }\end{array}$ & $\begin{array}{l}\text { March-April-May } \\
\text { averaging step }\end{array}$ \\
\hline February averaging step & 1 & ,795” \\
\hline Pearson Correlation & $1,526 \mathrm{E} 7$ &, 000 \\
\hline Sig.(2.tailed) & 150 & $1,148 \mathrm{E} 7$ \\
\hline Covariance & & 150 \\
\hline \multicolumn{3}{|l|}{$\mathrm{N}$} \\
\hline March-April-May averaging step & ,795” & 1 \\
\hline Pearson Correlation &, 000 & \\
\hline Sig.(2.tailed) & $1,148 \mathrm{E} 7$ & $1,368 \mathrm{E} 7$ \\
\hline Covariance & 150 & 150 \\
\hline $\mathrm{N}$ & & \\
\hline
\end{tabular}

According to the results in the table, the significance rate is less than 0.05 and it is seen that there is a significant and positive relationship between the stepping frequencies before the lecture and the stepping frequencies after the lecture $(\mathrm{r}$ $=(150)=, 79, \mathrm{p}=<0.001)$. According to these results, H1 hypothesis was accepted. The existence of a positive relationship between variables indicates that the two variables change together. 
Table 5. Correlation relation between demographic variable and first-last step

\begin{tabular}{|c|c|c|c|c|c|c|}
\hline & & gender & age & Distance From & First $\quad$ test & Final test \\
\hline & & & & $\begin{array}{l}\text { The Home Of } \\
\text { Faculty }\end{array}$ & $\begin{array}{l}\text { (febrary } \\
\text { average) }\end{array}$ & $\begin{array}{l}\text { (march-april-may step } \\
\text { avrage) }\end{array}$ \\
\hline Gender & Pearson & 1 & ,001 &, 081 & 059 & 003 \\
\hline Correlation Sig.(2-tailed) & & 150 & ,991 & 324 & 471 & ,970 \\
\hline & & & 150 & 150 & 150 & 150 \\
\hline age & & ,001 & 1 &, 011 & 059 & ,009 \\
\hline Correlation Sig.(2-tailed) & & & & & & \\
\hline $\mathrm{N}$ & & ,991 & & ,894 & ,471 & ,917 \\
\hline & & 150 & 150 & 150 & 150 & 150 \\
\hline distance from the home of & faculty & ,081 & 011 & 1 &,- 030 &,- 008 \\
\hline Correlation Sig.(2-tailed) & & ,324 & ,894 & 150 & ,716 & ,918 \\
\hline $\mathrm{N}$ & & 150 & 150 & & 150 & 150 \\
\hline First test & & 059 &, 059 &,- 030 & 1 & ,795” \\
\hline (febrary step average) & & ,471 & ,471 & ,716 & &, 000 \\
\hline Correlation Sig.(2-tailed) & & & & & & \\
\hline $\mathrm{N}$ & & 150 & 150 & 150 & 150 & 150 \\
\hline Final test & & ,003 & ,009 &,- 008 & ,795” & 1 \\
\hline (march-april-maystep avrage) & & ,970 & ,917 & ,918 & ,000 & \\
\hline Correlation & & & & & & \\
\hline $\begin{array}{l}\text { Sig.(2-tailed) } \\
\mathrm{N}\end{array}$ & & 150 & 150 & 150 & 150 & 150 \\
\hline
\end{tabular}

$\mathrm{H}_{2}$ : There is a significant relationship between demographic information and stepping average.

Whether or not the number of steps taken before and after the recreation lesson was related to demographic variables was tested by simple correlation analysis. The results of the analysis showed that there was no significant relationship between the demographic variables before and after the recreational course.

According to these results $\mathrm{H}_{2}$ hypothesis was not accepted. In other words, no significant relationship was found between gender, age, place of residence and school distance with stepping frequency.

\section{Conclusion and Discussion}

The acceleration of migration to the big cities, especially from the rural regions to İstanbul, leads to an increase in psychosocial, cultural and economic problems, irregular urbanization Demirtaş, Güngör and Demirtaş (2017) in cities and elements preventing physical activities. Within the framework of the research, the fact that the students studying in the faculty of sports sciences came to Istanbul from various regions has a significant role. After giving recreation lessons to these students, the relationships and differences between daily stepping frequencies were examined. A significant relationship was found between the students' averages before taking the course, in February and 12 weeks after taking the course. In accordance with the content of the course, the benefits of active-reactive activities performed in leisure times in terms of health, mental and psychological were examined. Within the scope of the research, it has been determined that there was a positive increase between the steps taken before the recreation training and the stepping frequency after the lecture. There was some information such as gender, age and the distance between the place of residence and the school, daily-stepping information, as well. The studies of Balc1 and Illhan (2006) show that the university students, females in particular, are less interested in activities with active participation and spare less time for such activities. Consequently, the students stated that they were more willing to participate in activities such as the activities carried out within the university or the sporting organizations of the university clubs Balc1 (2006). Within the scope of the research, the fact that there is a positive increase between the steps taken before and after the lecture supports our study. In our study, it was found that this situation showed a significant difference. As a result of scientific research, it was found that university students had difficulty in participating in leisure activities in general, and female students were more passive and shy than male students Özşaker (2012). In the study carried out by Terzioğlu and Yazıcı (2003), when evaluating the leisure time, gender and the education field was found to be effective. In our study, no significant relationship was found between gender and area of study with stepping frequency.

In another study, university students stated that they could find leisure time, but they did not have a picnic area, that the parks were not large enough and the parks were not sufficient Sabbağ and Aksoy (2011). To make people more successful in their lives, local governments should implement policies to be physically active and implement these policies WTO (2006). People should be encouraged to walk and ride bicycles by limiting the use of cars, especially in the cities. Walking and running trails should be organized regularly by providing access to green areas, national parks via public transport. Leisure time education is a training for providing an effective and useful evaluation of leisure time. By this study, the importance of leisure time evaluation activities and the importance of increasing this awareness by taking the course curriculum in all schools has emerged. Therefore, attention should be paid to the importance of social, 
mental and physical health effects of recreational activities performed in leisure time. The activities that enable take away from computers or staying at homes inactively should be taken into local administration and university programs and should be supported. In addition, recreation activities should be encouraged by collective participation and awareness should be increased by organizing recreational activities in institutions and university education programs. In the light of this information, it was determined that the students wanted a healthier and psychologically comfortable environment with the expression of the recreation course. On the other hand, it should be noted that the results of the research are limited to a specific sample and cannot be generalized.

\section{References}

Balc1, V., \& Demirtaş, P. (2002). Investigation of University student participation in leisure activities in Ankara, International Sport Congress, 123-131,Antalya.

Balcı, V., \& İlhan, İ. (2006) . The determinatıon student's paticipatıon levels to recreational activities in Unıversities of Turkey, Spormetre, Journal of Physical Education and Sports, 4(1), 11-18. doi:10.1501/Sporm.

Demir, C. (2003). Effects of demographic characteristics on sportive activity preferences, an application for university youth, Youth, Leisure and Outdoor Sports Symposium, Ankara.

Demirtaş, Ş. G., \& Demirtaş, R. N. (2017). Healty aging and physical activity: the contribution of individual, pschosocial and environmental features to this, Osmangazi Journal of Medicine. ISSN:1305-4953

Mansuroğlu, S. (2002). Determination of leisure characteristics and outdoor recreation tendencies for students of Akdeniz University, Akdeniz University, Journal of the Faculty of Agriculture, 15(2), 53-62.

Mc, A. (2001). Outdoors for everyone:opportunities that include people with disabilities, Parks And Recreation. 36(8), 24-36.

Önsoy, C. (1984). Investigation of the use of the area in the Iskenderun coastal area in accordance with the ecological planning principles Ç.Ü. School of Natural and Applied Sciences, Department of Landscape Architecture, PhD Thesis, Adana, 236.

Özer, K. (2006). Physical Fitness, Nobel Publication.2. March, 21-22.

Özşaker, M. (2012). A Study on the Reasons of Non-Participation of Youth in Free Time Activities, Selçuk University Journal of Physical Education and Sport Science, 14(1), 126-131.ISSN: 1300-9915.

Pate, R., Blair, S., \& Haskell, W. (1995). Physical Activity and Public Health. A Recommendation from the Centers for Disease Control and Prevention and the American College Sports Medicine, Jama, 402-407. https://doi.org/10.1001/jama.1995.03520290054029

Sabbağ, Ç., \& Aksoy, E. (2011). The Leisure Time Avtivities of Uiversity Students and Governmental Staff:Adiyaman Case, Mehmet Akif Ersoy University Journal of Social Sciences Institute ISSN:1309-1387, 3

Süzer, M. (1997). Leisure Habits of University Students, Hacettepe University. Social Sciences Institute. Master thesis.

Terzioğlu, A., \& Yazıc1, M., (2003). Discernment of the leisure time of university students (Atatürk University Case), Journal of Erzincan Faculty of Education, 5. ISSN:2148-7758

U.S. Department of Health and Human Services (1996). Physical Activity and Heath:A Report of the Surgeon General, Atlanta, 3-6.

WTO (2006). Supporting Physical Activity and Active Life in Urban Environment and the Role of Local Governments, 1st Edition, 2006, 17-40.

Yağmur, R. (2006). Students in Different Departments, Free Time Activities Comparison, Afyon Kocatepe University, Master Thesis.

Zorba, E.(1999). Sports and Physical Fitness for Everyone. 1.Part. Ankara.

\section{Copyrights}

Copyright for this article is retained by the author(s), with first publication rights granted to the journal.

This is an open-access article distributed under the terms and conditions of the Creative Commons Attribution license which permits unrestricted use, distribution, and reproduction in any medium, provided the original work is properly cited. 